\title{
CONCENTRATIONS OF SELECTED METALS (NA, K, CA, MG, FE, CU, ZN, AL, NI, PB, CD) IN COFFEE KONCENTRACIJE IZBRANIH KOVIN (NA, K, CA, MG, FE, CU, ZN, AL, NI, PB, CD) V KAVI
}

\author{
Grażyna ADLER ${ }^{1 *}$, Arkadiusz NĘDZAREK², Agnieszka TÓRZ²
}

\begin{abstract}
'Pomeranian Medical University, Department of Studies in Antropogenetics and Biogerontology, Żotnierska 48, 71-210 Szczecin, Poland

${ }^{2}$ West Pomeranian University of Technology in Szczecin, Department of Aquatic Sozology, Kazimierza Królewicza 4, 71-550 Szczecin, Poland
\end{abstract}

\section{ABSTRACT}

Keywords: coffee infusion, green coffee, roasted coffee, metal concentrations
Introduction: The health benefits and detrimental effects of coffee consumption may be linked to chemical compounds contained in coffee beans. The aim of our study was to evaluate the concentration of sodium ( $\mathrm{Na})$, potassium $(\mathrm{K})$, calcium $(\mathrm{Ca})$, magnesium $(\mathrm{Mg})$, iron $(\mathrm{Fe})$, copper $(\mathrm{Cu})$, zinc $(\mathrm{Zn})$, aluminum $(\mathrm{Al})$, nickel $(\mathrm{Ni})$, lead $(\mathrm{Pb})$ and cadmium $(\mathrm{Cd})$ in green and roasted samples of coffee beans purchased in Bosnia and Herzegovina, and to determine the potential health implications at current consumption level.

Methods: The concentrations were determined using a microwave high-pressure mineralization and atomic absorption spectrometer that measures total metal (ionic and non-ionic) content.

Results: The average metal concentrations ( $\mu \mathrm{g}$ element/g coffee) in the green coffee beans were; Na: 18.6 , K: 19898, Ca: 789, Mg: 1758, Fe: 60, Cu: 14, Zn: 3.6, Al: 4.2, Ni: 0.415, Pb: 0.076, and Cd: 0.015, while, in the roasted; Na: 23, K: 23817, Ca: 869, Mg: 1992, Fe: 41.1, Cu: 11.4, Zn: 5.41, Al: 4.19, Ni: 0.88, Pb: 0.0169, and Cd: 0.0140 .

Conclusion: The level of investigated metals at the present level of consumption of coffee in Bosnia falls within the limits recommended as safe for health.

Uvod: Zdravstvene prednosti in škodljivi učinki uživanja kave so lahko povezani z kemijskimi spojinami v kavnih zrnih. Cilj študije je oceniti koncentracije naslednjih spojin: natrij (Na), kalij (K), kalcij (Ca), magnezij $(\mathrm{Mg})$, železo $(\mathrm{Fe})$, baker (Cu), cink ( $\mathrm{Zn})$, aluminij (Al), nikelj (Ni), svinec $(\mathrm{Pb})$ in kadmij $(\mathrm{Cd})$ v zelenih in praženih vzorcih kavnih zrn, kupljenih $v$ Bosni in Hercegovini, ter določiti morebitne zdravstvene posledice glede na trenutno raven uživanja.

Metode: Koncentracije so bile določene z uporabo visokotlačne mineralizacije z mikrovalovi in atomske absorpcijske spektrometrije, ki merijo skupno vsebino kovine (ionska in neionska).

Rezultati: Povprečna koncentracija kovin ( $\mu$ g elementa/g kave) v zelenih kavnih zrnih je bila: Na: 18,6, K: 19898, Ca: 789, Mg: 1758, Fe: 60, Cu: 14, Zn: 3,6, Al: 4,2, Ni: 0,415, Pb: 0,076 in Cd: 0,015; v praženih zrnih pa: Na: 23, K: 23817, Ca: 869, Mg: 1992, Fe: 41,1, Cu: 11,4, Zn: 5,41, Al: 4,19, Ni: 0,88, Pb: 0,0169 in Cd: 0,0140.

Zaključek: Raven preverjenih kovin na trenutni stopnji uživanja kave $v$ Bosni in Hercegovini se nahaja znotraj omejitev, ki so priporočene kot zdrave za zdravje. 


\section{INTRODUCTION}

Coffee is, after water, amongst the most popular beverages consumed in the world (1). Numerous studies suggest that moderate coffee consumption has beneficial health impacts on humans. Coffee infusions show protective potential against oxidative stress through the presence of antioxidants and active components (24). They increase the antioxidant plasma capacity and might increase glutathione levels and thus reduce the levels of DNA damage $(5,6)$. Furthermore, some studies imply that habitual coffee consumption could protect against Parkinson's and Alzheimer's disease $(7,8)$. Coffee consumption may also be linked to improvements in fecal microbiota and colonic fermentation, may reduce the risk of developing liver, colorectal and prostate cancer as well as brain tumors (9-11). The meta-analysis by Lukic et al. confirmed the protective effect of coffee consumption on the risk of endometrial cancer. Additionally, authors suggest that increased coffee intake might be particularly beneficial for women with obesity (12). On the other hand, increased long-term coffee consumption may cause, among others: increasing plasma homocysteine and LDL (Low Density Lipoprotein) level, gastrointestinal disturbances $(4,13,14)$. Moreover, repeated doses of coffee throughout the day may be linked to an elevation of cortisol secretion in the afternoon hours (15). What is even more, maternal consumption of coffee during pregnancy may increase the risk of the occurrence acute childhood leukemia $(16,17)$. It is also suggested that coffee consumption is a risk factor for osteoporosis in postmenopausal women (18).

The contamination of food may be caused by various compounds found in the environment e.g. high doses of fertilizers or plant protection chemicals. These compounds, taken with food and then absorbed in the digestive tract, may have an influence on body cells and tissues. On the other hand, potential contamination may derive from package and storage, pollution, fungi and molds $(19,20)$. The amount of compounds taken with coffee infusions depend on their contents in coffee beans, level of consumption and pattern of drinking coffee infusions, which is linked to the geographical region. In Europe, the highest coffee consumption is observed in Finland, $12 \mathrm{~kg}$ per capita/year, and in Bosnia and Herzegovina (B\&H) it is $6.2 \mathrm{~kg}$ per capita/year (21).

The aim of this study was to evaluate the concentration of selected metals: $\mathrm{Na}, \mathrm{K}, \mathrm{Ca}, \mathrm{Mg}, \mathrm{Fe}, \mathrm{Cu}, \mathrm{Zn}, \mathrm{Al}, \mathrm{Ni}, \mathrm{Pb}$ and $\mathrm{Cd}$ in coffee and determine the difference in their concentration between green and roasted coffee beans. Additionally, we investigated if the level of studied metals, at the current level of consumption of coffee in $\mathrm{B \& H}$, is within the recommended limits safe for health.

\section{MATERIALS AND METHODS}

Coffee infusions in Bosnia are prepared in a traditional way, which is widespread in the Balkans, the Middle East, Eastern Europe, North Africa, the Caucasus and Bali, known as Turkish coffee. During the first step roasted ground coffee is added to boiling water in the pot and heated until the foam level is rising. Afterwards, the coffee is flooded with a small amount of cold water. At this time the coffee is partially precipitating. Next, the coffee is heated until the foam level rises again. After a few minutes the coffee is ready to drink (19).

\subsection{Coffee Samples}

The coffee beans were roasted and purchased in small local stores in Sarajevo, B\&H. Coffee roasting was carried out in specialized drum furnaces by store employees. The process of roasting can be described as follows: the gas flame under the drum heats and burns the coffee beans, the temperature being around $200^{\circ} \mathrm{C}$ immediately after roasting. After this process, the beans are cooled down by air at ambient temperature.

We tested two samples of green coffee beans ( $G$ 1-2) and six (R 1-6) roasted. Two pairs of the same coffee beans, before and after roasting were examined: $G 1 a$ and $R 1 \mathrm{a}$ and $\mathrm{G} 2 \mathrm{~b}$ and $\mathrm{R} 2 \mathrm{~b}$. The measurements of metal concentration were performed in triplicate from each coffee sample.

\subsection{Instrument}

Grinded coffee beans weighing $1 \pm 0.01 \mathrm{~g}$ were digested with a mixture of concentrated $\mathrm{HNO} 3$ and $\mathrm{HClO} 4$ acids (5 and $1 \mathrm{~mL}$, respectively) and then diluted to $25 \mathrm{~mL}$ with water. Coffee infusions were prepared by boiling $10 \pm 0.1$ $\mathrm{g}$ of coffee in $200 \mathrm{~mL}$ of water. Coffee brewing time was 5 min. After cooling the infusions to $20^{\circ} \mathrm{C}, 25 \mathrm{~mL}$ were taken for mineralization with a mixture of concentrated $\mathrm{HNO} 3$ and $\mathrm{HClO} 4$ acids ( 2.5 and $1 \mathrm{~mL}$, respectively). After mineralization, the samples were diluted to $50 \mathrm{~mL}$ with water.

Mineralizations of coffee beans and coffee infusions were carried out using a high pressure microwave mineralizer, Speedwave Xpert (Bergof, Eningen, Germany). Metals were determined using the Hitachi Polarized Zeeman Atomic Absorption Spectrometer ZA3000 Series (Hitachi High-Technologies Corporation, Tokyo, Japan). Ca, K, Na, $\mathrm{Mg}$ were determined using the flame atomic absorption spectroscopy method (FAAS) in the air-acetylene flame with Zeeman correction. $\mathrm{Fe}, \mathrm{Cu}, \mathrm{Zn}, \mathrm{Al}, \mathrm{Pb} \mathrm{Cd}$ and $\mathrm{Ni}$ were measured by the flameless technique in a graphite furnace atomic absorption spectroscopy (GFAAS). Mili- $Q$ water (18.2M $\Omega$ ) was used to prepare coffee infusions and dilutions. Standardized calibration solutions 
dedicated for metal determination by atomic absorption with a concentration of $1000 \mathrm{mg} / \mathrm{L}$ were used for the calibration curves; for $\mathrm{Mg}, \mathrm{Ca}, \mathrm{K}, \mathrm{Na}$ and Fe (Scharlau Chemie s.a., Barcelona, Spain), and for $\mathrm{Zn}, \mathrm{Cu}, \mathrm{Pb}, \mathrm{Cd}$ $\mathrm{Ni}$ and Al (Merck, Darmstadt, Germany). Reliability of the analytical method was tested using a reference material - fish muscle ERM-BB422 (European Reference Materials, European Commission - Joint Research Centre, Institute for Reference Materials and Measurements, Geel, Belgium). The recovery of elements was in the range of $95-105 \%$, and the precision for the reference material was 1.2-10.1\%.

\subsection{Statistical Analysis}

The measurements of metal concentration were performed in triplicate from each coffee sample. For quantitative variables in each group, the minimum and maximum values, the arithmetic mean, SD and IQR were calculated. The differences of metals' concentration were performed using the ANOVA test.

\section{RESULTS}

The ranges of values of metals' concentration $(\mu \mathrm{g}$ element/g coffee) in the samples of green coffee beans are presented in Table $1 \mathrm{a}$. In the samples of roasted coffee beans, there were: Na: 13.0-36.3, K: 20300-32933, Ca 750-939, Mg: 1800-2127, Fe: 35.2-49.1, Cu: 6.5-16.5, $\mathrm{Zn}: 4.96-6.18$, Al: 1.74-6.01, Ni: 0.69-1.16, Pb: 0.01150.0215 and $\mathrm{Cd}: 0.0111-0.0222 \mu \mathrm{g} / \mathrm{g}$ of coffee. The average contents of $\mathrm{Na}, \mathrm{K}, \mathrm{Ca}, \mathrm{Mg}, \mathrm{Zn}, \mathrm{Ni}$ and $\mathrm{Cd}$ in roasted coffee samples compared to green coffee were higher, while average contents for Al have not changed, and for three metals: $\mathrm{Fe}, \mathrm{Cu}$ and $\mathrm{Pb}$ were lower (see Table $1 \mathrm{a}$ and $1 \mathrm{~b}$ ). The ranges of values of metals' concentration $(\mu \mathrm{g} / 100 \mathrm{~mL})$ in the coffee infusions were as follows: $\mathrm{Na}$ : 25.5-63.9, K: 81467-132333, Ca: 1037-1827, Mg: 4600-8463, Fe: 8.93-24.50, Cu: 1.20-6.86, Zn: 5.53-13.17, Al: 2.03-8.43, $\mathrm{Ni}: 0.78-1.82$, Pb: 0.133-0.558, and Cd: 0.036-0.061 (see Table 2).

Table 1a. Concentration of metals in green coffee $(\mu \mathrm{g} / \mathrm{g}=\mathrm{ppm})$.

\begin{tabular}{lcccccccccccc}
\hline No of green coffee & $\mathrm{Na}$ & $\mathrm{K}$ & $\mathrm{Ca}$ & $\mathrm{Mg}$ & $\mathrm{Fe}$ & $\mathrm{Cu}$ & $\mathrm{Zn}$ & $\mathrm{Al}$ & $\mathrm{Ni}$ & $\mathrm{Pb}$ & $\mathrm{Cd}$ \\
\hline G1a & 10.6 & 19583 & 695 & 1733 & 75.1 & 18.5 & 4.04 & 5.65 & 0.44 & 0.1436 & 0.0145 \\
G 2b & 26.6 & 20213 & 882 & 1783 & 45.2 & 9.4 & 3.09 & 2.73 & 0.39 & 0.0084 & 0.0152 \\
Mean & 18.6 & 19898 & 789 & 1758 & 60 & 14 & 3.6 & 4.2 & 0.415 & 0.076 & 0.015 \\
SD & \pm 11.31 & \pm 445.48 & \pm 132.23 & \pm 35.36 & \pm 21.14 & \pm 6.43 & \pm 0.67 & \pm 2.06 & \pm 0.04 & \pm 0.0956 & \pm 0.0005 \\
IQR & $(8)$ & $(315)$ & $(93.5)$ & $(25)$ & $(14.95)$ & $(4.55)$ & $(0.48)$ & $(1.46)$ & $(0.03)$ & $(0.068)$ & $(0.0004)$ \\
\hline
\end{tabular}

Table 1b. Concentration of metals in roasted coffee $(\mu \mathrm{g} / \mathrm{g}=\mathrm{ppm})$.

\begin{tabular}{lcccccccccccc}
\hline No of roasted coffee & $\mathrm{Na}$ & $\mathrm{K}$ & $\mathrm{Ca}$ & $\mathrm{Mg}$ & $\mathrm{Fe}$ & $\mathrm{Cu}$ & $\mathrm{Zn}$ & $\mathrm{Al}$ & $\mathrm{Ni}$ & $\mathrm{Pb}$ & $\mathrm{Cd}$ \\
\hline R 1a & 24.2 & 20300 & 868 & 2127 & 41.8 & 16.5 & 5.07 & 3.53 & 0.72 & 0.0202 & 0.0124 \\
R 2b & 36.3 & 22133 & 888 & 2120 & 49.1 & 10.3 & 6.18 & 6.01 & 0.69 & 0.0131 & 0.0126 \\
R 3 & 21.6 & 32933 & 864 & 2097 & 37.4 & 13.3 & 5.16 & 4.25 & 1.14 & 0.0115 & 0.0111 \\
R 4 & 14.3 & 25167 & 904 & 2007 & 36.2 & 6.9 & 4.96 & 4.44 & 0.71 & 0.0196 & 0.0222 \\
R 5 & 13.0 & 20867 & 750 & 1803 & 46.7 & 14.6 & 5.89 & 5.17 & 0.84 & 0.0215 & 0.0120 \\
R 6 & 28.6 & 21500 & 939 & 1800 & 35.2 & 6.5 & 5.22 & 1.74 & 1.16 & 0.0155 & 0.0135 \\
Mean & 23 & 23817 & 869 & 1992 & 41.1 & 11.4 & 5.41 & 4.19 & 0.88 & 0.0169 & 0.0140 \\
SD & \pm 8.80 & \pm 4779.12 & \pm 64.30 & \pm 153.91 & \pm 5.80 & \pm 4.13 & \pm 0.50 & \pm 1.47 & \pm 0.22 & \pm 0.0041 & \pm 0.0041 \\
IQR & $(11.4)$ & $(3383)$ & $(35)$ & $(260.3)$ & $(9)$ & $(6.5)$ & $(0.63)$ & $(1.28)$ & $(0.35)$ & $(0.006)$ & $(0.001)$ \\
\hline
\end{tabular}

Samples G 1 and G 2- green; R 1 to R 6-roasted; G $1 a$ and R $1 a$ and G $2 b$ and R 2b- pairs of the same coffee beans, before and after roasting; SD- standard deviation; IQR- interquartile range 
Table 2. Concentration of metals in coffee infusions, $(\mu \mathrm{g} / 100 \mathrm{~mL})$.

\begin{tabular}{lccccccccccc}
\hline No of coffee & $\mathrm{Na}$ & $\mathrm{K}$ & $\mathrm{Ca}$ & $\mathrm{Mg}$ & $\mathrm{Fe}$ & $\mathrm{Cu}$ & $\mathrm{Zn}$ & $\mathrm{Al}$ & $\mathrm{Ni}$ & $\mathrm{Pb}$ & $\mathrm{Cd}$ \\
\hline R 1a & 57.0 & 86933 & 1277 & 6593 & 11.30 & 2.82 & 6.10 & 4.93 & 0.78 & 0.558 & 0.042 \\
R 2b & 59.8 & 95667 & 1633 & 8463 & 24.50 & 2.62 & 13.17 & 4.63 & 1.63 & 0.357 & 0.059 \\
R 3 & 42.8 & 132333 & 1037 & 6893 & 15.87 & 6.86 & 6.13 & 8.33 & 1.62 & 0.163 & 0.041 \\
R 4 & 25.5 & 103533 & 1233 & 4600 & 8.93 & 2.15 & 5.53 & 5.40 & 0.82 & 0.133 & 0.036 \\
R 5 & 19.6 & 81467 & 1263 & 7380 & 16.13 & 2.70 & 6.67 & 8.43 & 1.04 & 0.192 & 0.061 \\
R 6 & 63.9 & 95267 & 1827 & 8073 & 15.27 & 1.20 & 8.13 & 2.03 & 1.82 & 0.140 & 0.046 \\
Mean & 44.8 & 99200 & 1378 & 7000 & 15.33 & 3.04 & 7.62 & 5.63 & 1.29 & 0.257 & 0.048 \\
SD & \pm 18.71 & \pm 17941 & \pm 292.36 & \pm 1369.18 & \pm 5.33 & \pm 1.95 & \pm 2.86 & \pm 2.43 & \pm 0.46 & \pm 0.168 & \pm 0.010 \\
IQR & $(29.3)$ & $(12550)$ & $(303.5)$ & $(1231.8)$ & $(3.8)$ & $(0.5)$ & $(1.66)$ & $(2.89)$ & $(0.75)$ & $(0.17)$ & $(0.015)$ \\
\hline
\end{tabular}

SD- standard deviation; IQR- interquartile range

All analyzed metals passed from ground coffee beans to coffee infusions. The highest average diffusion showed $\mathrm{K}$ and $\mathrm{Mg}$, more than 83 and $70 \%$, respectively. The average level of diffusion from 38 to $27 \%$ showed: $\mathrm{Na}, \mathrm{Pb}, \mathrm{Ca}, \mathrm{Ni}$ and $\mathrm{Zn}$ and Al. While, the lowest: $\mathrm{Fe}, \mathrm{Cu}$ and $\mathrm{Cd}$, each less than $11 \%$ (see Table 3).

Table 3. Penetration of metals to coffee infusions, (\%).

\begin{tabular}{lccccccccccc}
\hline No of coffee & $\mathrm{Na}$ & $\mathrm{K}$ & $\mathrm{Ca}$ & $\mathrm{Mg}$ & $\mathrm{Fe}$ & $\mathrm{Cu}$ & $\mathrm{Zn}$ & $\mathrm{Al}$ & $\mathrm{Ni}$ & $\mathrm{Pb}$ & $\mathrm{Cd}$ \\
\hline R 1a & 47.1 & 85.6 & 29.4 & 62.0 & 5.4 & 3.4 & 24.0 & 28.0 & 55.3 & 6.8 & 21.5 \\
R 2b & 32.9 & 86.4 & 36.8 & 79.8 & 10.0 & 5.1 & 42.6 & 15.4 & 54.4 & 9.4 & 47.6 \\
R 3 & 39.6 & 80.4 & 24.0 & 65.8 & 8.5 & 10.3 & 23.8 & 39.2 & 28.2 & 7.3 & 28.1 \\
R 4 & 35.7 & 82.3 & 27.3 & 45.8 & 4.9 & 6.2 & 22.3 & 24.3 & 13.6 & 3.2 & 23.2 \\
R 5 & 30.2 & 78.1 & 33.7 & 81.8 & 6.9 & 3.7 & 22.6 & 32.6 & 17.9 & 10.3 & 24.9 \\
R 6 & 44.7 & 88.6 & 38.9 & 89.7 & 8.7 & 3.7 & 31.1 & 23.3 & 18.0 & 6.8 & 31.4 \\
\hline
\end{tabular}

The analysis in pairs of the same coffee beans, before and after roasting showed that, in roasted coffee beans ( $R$ 1a), concentrations of $\mathrm{Na}, \mathrm{Ca}, \mathrm{Zn}$ and $\mathrm{Ni}$ were significantly higher than in green coffee beans ( $G 1 a)$, while in roasted beans $\mathrm{R} 2 \mathrm{~b}$, concentrations of $\mathrm{Na}, \mathrm{K}, \mathrm{Mg}, \mathrm{Zn}, \mathrm{Al}, \mathrm{Ni}$ and $\mathrm{Pb}$ were significantly higher than in green beans $\mathrm{G} 2 \mathrm{~b}$. It should be noted that, in green coffee beans ( $G 1 a)$, concentrations of $\mathrm{Al}$ and $\mathrm{Pb}$ were significantly higher than in roasted coffee beans ( $\mathrm{R} 1 \mathrm{a})$ (see Table 4$)$.
Table 4. Empirical levels of significance for differences of metals' concentrations by ANOVA test.

\begin{tabular}{lcc}
\hline Metal & G 1a vs. R 1a & G 2b vs. R 2b \\
\hline $\mathrm{Na}$ & $<0.001^{*}$ & $0.013^{*}$ \\
$\mathrm{~K}$ & 0.509 & $0.008^{*}$ \\
$\mathrm{Ca}$ & $<0.001^{*}$ & 0.802 \\
$\mathrm{Mg}$ & 0.050 & $0.003^{*}$ \\
$\mathrm{Fe}$ & 0.004 & 0.427 \\
$\mathrm{Cu}$ & 0.335 & 0.235 \\
$\mathrm{Zn}$ & $0.017^{*}$ & $0.007^{*}$ \\
$\mathrm{Al}$ & $0.004^{*}$ & $0.0066^{*}$ \\
$\mathrm{Ni}$ & $0.020^{*}$ & $0.012^{*}$ \\
$\mathrm{~Pb}$ & $<0.001^{*}$ & $0.030^{*}$ \\
$\mathrm{Cd}$ & 0.173 & 0.135
\end{tabular}

*statistically significant differences 


\section{DISCUSSION}

Coffee beans from miscellaneous geographical areas are characterized by different organoleptic features and chemical composition $(20,22,23)$. The final content of elements in the coffee beans is also influenced by technological processes: drying, burning, roasting and storage $(19,20)$. Mineral components and toxic elements pass to the beverage during the brewing process. Their final content in infusion is influenced by methods of brewing and occurrence other mineral components that could be present e.g. in water used to prepare beverage (24).

On the one hand metals play an important role in the human body e.g. as components of enzymes. On the other hand, their increased supply may cause adverse health effects, like damage to internal organs, endocrine disruption and poor reproductive capacity and genotoxicity linked to cancers. They may also be involved in the pathogenesis of neurodegenerative diseases (25-28). Moreover, it should be noted that lead accumulates in the human body, causing distant effects (29).

The tolerable upper intake level $(\mathrm{mg})$, which exceeds a recommended intake for the examined elements per year (for adults with average body weight $70 \mathrm{~kg}$ ), is as follows: $\mathrm{Na}: 730000, \mathrm{~K}: 2775000-127750000$ (probably oral lethal dose for human varies), Ca: 912500, Cu: 1825, Zn: 9125, Al: $3650, \mathrm{Ni}: 365, \mathrm{~Pb}: 91, \mathrm{Cd}: 9.125$. Very large doses of magnesium, higher than $1825000 \mathrm{mg}$, are associated with its toxicity, and oral dose of $1533000 \mathrm{mg}$ Fe can be lethal (30-34).

The exposure on metals from coffee is usually a long-term low-concentration exposure. Coffee is a rich source of elements and compounds. The data on the differences in concentrations of metals in coffee beans is important due to the popularity of this beverage and the occurrence of a safe consumption limit for elements that come from the diet, dietary supplements and the environment and topped up by coffee. In addition, compounds contained in coffee may affect the course of treatment e.g. in bipolar affective disorder, by affecting the blood concentration of lithium (35).

The findings we obtained suggest that roasting of coffee beans may affect the content of some metals, and drying may cause increase in concentration of the elements. In coffee samples before roasting the concentrations of $\mathrm{Na}$, $\mathrm{K}, \mathrm{Ca}, \mathrm{Mg}, \mathrm{Zn}, \mathrm{Ni}$ (for G 1a) and K, Mg, Zn, Ni, Pb (for G 2b) were lower than after the roasting process. However, in coffee sample $\mathrm{G} 1 \mathrm{a}$ : $\mathrm{Fe}, \mathrm{Cu}$ and $\mathrm{Pb}$, the concentration of metals was lower after roasting. The ranges of estimated intake of investigated metals per capita/year, based on coffee consumption obtained from (21) were: Na: 80.6225.1; K: 125860-204184.6; Ca: 4650-5821.8; Mg: 1116013187.4; Fe: 218.2-304.4; Cu 40.3-102.3; Zn:30.8-38.3; Al:
10.8-37.3; Ni: 4.3-7.2; Pb: 0.07-0.13; Cd: 0.07-1.14 mg/ per capita/year, and none of the metals tested exceeded the level that could pose a health risk. Our previous study of coffee purchased in Bosnia has shown similar values for $\mathrm{Ni}$ intake 3.83-5.68, but higher values for $\mathrm{Pb}$ 4.76-7.56 $\mathrm{mg} /$ per capita/year (36). Unfortunately, in the previous study, we did not investigate green coffee beans.

Generally, the number of reports concerning content of metals in green coffee beans is limited in comparison to roasted coffee beans reports. Stelmach et al. and Nogaim et al., have analyzed mineral components in green coffee beans from Africa, America, Asia and Yemen, respectively $(37,38)$. Authors reported similar to ours values for $\mathrm{Cu}$ and Fe. However, Nogaim et al. have observed higher values for $\mathrm{Pb}(0.599-7.989 \mu \mathrm{g} / \mathrm{g})$ in Yemeni green coffee beans (38). This confirms that coffee beans growing on different geographical areas are characterized by different chemical composition. Unfortunately, in this research the content of elements after roasting was not determined. Taking into account the results obtained in other studies, which showed that the content of $\mathrm{Pb}$ after roasting compared to green coffee beans increased, it would be an interesting issue to investigate. Długaszek et al. have assessed the content of selected elements in Colombian coffee beans purchased in Poland. Authors observed similar Al and Ca concentrations, but lower Mg, Fe, Zn, Ni, $\mathrm{Cu}$ and $\mathrm{Cd}$ in comparison to our results for Brazilian coffee beans purchased in Bosnia. The authors observed higher than ours $\mathrm{Pb}$ content $(0.02-0.06 \mu \mathrm{g} / \mathrm{g})$, which is linked to higher estimated intake of $\mathrm{Pb}: 0.122-0.366 \mathrm{mg}$ per capita/ year. Additionally, a lower intake of coffee in Poland than in Bosnia has been observed (2.4 vs. $6.2 \mathrm{~kg}$ per capita /year, respectively) (24). Other authors, Grembecka et al. have also investigated the metal content in roasted coffee beans from Africa, America, Asia and Oceania. They received values comparable to ours for: $\mathrm{Zn}, \mathrm{Cu}, \mathrm{Fe}$ and $\mathrm{Ni}$, but $\mathrm{Pb}$ and $\mathrm{Cd}$ concentrations were below their method detection limits (23).

In 2015, Oliveira et al. have analyzed mineral contents in infusions prepared from roasted coffee beans from: Brazil, Ethiopia, Colombia, India, Mexico, Honduras, Guatemala, Papua New Guinea, Kenya, Cuba, Timor, Mussulo and China. Authors have noted similar values for $\mathrm{Na}$, as in our studies of coffee infusions, but lower values for: $\mathrm{Ca}$, $\mathrm{Mg}, \mathrm{K}$ and $\mathrm{Fe}$ (39). The authors observed that the mineral profiles of the beverages were linked to both, inter- and intracontinental differences. It is interesting that $\mathrm{Mn}$ and $\mathrm{Ca}$ were found to be the best chemical descriptors for origin of coffee beans. South American origin coffees were on average richer in the analyzed elements, except for $\mathrm{Ca}$, while coffee beans from Central America had lower mineral contents (excluding $\mathrm{Mn}$ ). Unfortunately, among the above mentioned studies authors rarely investigated these elements, so such comparison is impossible. 
Ashu and Chandravanshi studied content of selected metals in coffee infusions in Etiopian coffee beans and noted similar $\mathrm{Ca}, \mathrm{Fe}$ and $\mathrm{Cu}$ concentrations compared to our results, but higher values for $\mathrm{Na}$ and $\mathrm{Zn}$, and lower values for $\mathrm{K}$ and $\mathrm{Mg}(20) . \mathrm{Pb}$ and $\mathrm{Cd}$ concentrations were below their method detection limits, just like in research by Grembecka et al. (23).

Average intakes of $\mathrm{Na}, \mathrm{K}, \mathrm{Ca}, \mathrm{Mg}, \mathrm{Fe}, \mathrm{Cu}, \mathrm{Zn}, \mathrm{Al}, \mathrm{Ni}$, $\mathrm{Pb}$ and $\mathrm{Cd}$ (mg/per capita/year), based on the average metal content of roasted coffee purchased in Bosnia (see table $1 \mathrm{~b})$ and coffee consumption in B\&H were: 142.6, 147665.4, 5387.8, 12350.4, 254.82, 70.68, 33.54, 25.98, $5.46,0.105,0.071$ respectively. Note that the intake values are the entire population averages, which means that coffee drinkers will tend to ingest more coffee and metals than values shown.

Therefore further investigations are needed, especially on metals that have harmful effects on health, and also those that accumulate in the body, like $\mathrm{Pb}$. Research should focus on countries with high coffee consumption. Again, the fact that even low levels of some metals, e.g. zinc, may interfere with HDL (High Density Lipoprotein) concentrations, $\mathrm{Pb}$ is accumulated and the effects of its accumulation can be distant in time should be taken into account $(29,40)$.

\section{CONCLUSION}

All in all, the level of studied components in coffee purchased in Bosnia is within the recommended limits.

\section{CONFLICTS OF INTEREST}

The authors declare that they have no conflict of interest.

\section{FUNDING}

This study was funded by the West Pomeranian University of Technology and the Pomeranian Medical University, Szczecin, Poland.

\section{ETHICAL APPROVAL}

Not applicable.

\section{REFERENCES}

1. Reyes CM, Cornelis MC. Caffeine in the diet: country-level consumption and guidelines. Nutrients. 2018;15:10. doi: 10.3390/ nu10111772.

2. Messina G, Zannella C, Monda V, Dato A, Liccardo D, De Blasio S, et al. The beneficial effects of coffee in human nutrition. Biol Med (Aligarh). 2015;7:240. doi: 10.4172/0974-8369.1000240.

3. Odzakoviz B, Dzinic N, Kukric Z, Grujic S. Effect of roasting degree on the antioxidant activity of different Arabica coffee quality classes. Acta Sci Pol Technol Aliment. 2016;15:409-17. doi: 10.17306/J. AFS.2016.4.39.

4. Shateri Z, Djafarian K. Coffee consumption and coronary heart diseases: a mini-review. J Clin Nutr Diet. 2016;2:3. doi: 10.4172/2472-1921.100010.

5. Agudelo-Ochoa GM, Pulgarín-Zapata IC, Velásquez-Rodriguez $C M$, Duque-Ramírez M, Naranjo-Cano M, Quintero-Ortiz MM, et al. Coffee consumption increases the antioxidant capacity of plasma and has no effect on the lipid profile or vascular function in healthy adults in a randomized controlled trial. J Nutr. 2016;146:524-31. doi: 10.3945/ jn.115.224774.

6. Martini D, Del Bo' C, Tassotti M, Riso P, Del Rio D, Brighenti F, et al. Coffee consumption and oxidative stress: a review of human intervention studies. Molecules. 2016;21:979. doi: 10.3390/ molecules21080979

7. Tan EK, Chua E, Fook-Chong SM, Teo YY, Yuen Y, Tan L, et al. Association between caffeine intake and risk of Parkinson's disease among fast and slow metabolizers. Pharmacogenet Genomics. 2007;17:1001-5. doi: 10.1097/FPC.0b013e3282f09265.

8. Kotyczka C, Boettler U, Lang R, Stiebitz H, Bytof G, Lantz I, et al. Dark roast coffee is more effective than light roast coffee in reducing body weight, and in restoring red blood cell vitamin $\mathrm{E}$ and glutathione concentrations in healthy volunteers. Mol Nutr Food Res. 2011;55:1582-6. doi: 10.1002/mnfr.201100248.

9. Walton GE, Rastall RA, Martini RC, Williams CE, Jeffries RL, Gibson GR. A double-blind, placbo-controlled human study investigating the effects of caffee derived manno-oligosaccharides on the faecal microbiota of a healthy adult population. Int J Pro Pre. 2010;5:75-84.

10. Scazzina F, Del Rio D, Pucci T, Campanini E, Brighenti F. Coffee polyphenols and colonic fermentation: an in vivo study. Ann Nutr Metab. 2011;58:86-7.

11. Raj BJ, Priya VV, Gayathri R. Relationship between coffee consumption and cancer - a review. J Pharm Sci \& Res. 2016;8:424-7.

12. Lukic M, Guha N, Licaj I, van den Brandt PA, Stayner LT, Tavani A, et al. Coffee drinking and the risk of endometrial cancer: an updated meta-analysis of observational studies. Nutr Cancer. 2018;70:513-28. doi: 10.1080/01635581.2018.1460681.

13. Higdon J, Frei B. Coffee and health: a review of recent human research. Crit Rev Food Sci Nutr. 2006;46:101-23. doi: 10.1080/10408390500400009.

14. Cornelis M, El-Sohemy A. Coffee, caffeine, and coronary heart disease. Curr Opin Lipidol. 2007;18:13-9. doi: 10.1097/ MOL.0b013e3280127b04.

15. Lovallo WR, Whitsett TL, al' Absi M, Sung BH, Vincent AS, Wilson MF. Caffeine stimulation of cortisol secretion across the waking hours in relation to caffeine intake levels. Psychosom Med. 2005;67:734-9. doi: 10.1097/01.psy.0000181270.20036.06.

16. Cheng J, Su H, Zhu R, Wang X, Peng M, Song J, et al. Maternal coffee consumption during pregnancy and risk of childhood acute leukemia: a metaanalysis. Am J Obstet Gynecol. 2014;210:151.e1-10. doi: 10.1016/j.ajog.2013.09.026.

17. Thomopoulos TP, Ntouvelis E, Diamantaras AA, Tzanoudaki M, Baka $M$, Hatzipantelis $E$, et al. Maternal and childhood consumption of coffee, tea and cola beverages in association with childhood leukemia: a meta-analysis. Cancer Epidemiol. 2015;39:1047-59. doi: 10.1016/j.canep.2015.08.009. 
18. Kapetanovic A, Avdic D. Influence of coffee consumption on bone mineral density in postmenopausal women with estrogen deficiency in menstrual history. J H Sci. 2014;4:105-9. doi: 10.17532/ jhsci.2014.194.

19. Odzakovic B, Dzinic N, Grujic S, Kravic S, Jokanovic M. Sensory and physico-chemical evaluation of commercial coffees consumed in Banja Luka (Bosnia and Herzegovina) - Part 1. Agro Food Industry $\mathrm{Hi}$ Tech. 2015;26:52-5. doi: 10.7251/EEMSR6710.

20. Ashu R, Chandravanshi BS. Concentration levels of metals in commercially available Ethiopian roasted coffee powders and their infusions. Bull Chem Soc Ethiop. 2011;25:11-24. doi: 10.4314/bcse. v25i1.63356.

21. Mapped: The countries that drink the most coffee. Accessed May 28th, 2019 at: https://telegraph.co.uk/travel/maps-and-graphics/ countries-that-drink-the-most-coffee/.

22. Ranheim T, Halvorsen B. Coffee consumption and human healthbeneficial or detrimental? Mechanisms for effects of coffee consumption on different risk factors for cardiovascular disease and type 2 diabetes mellitus. Mol Nutr Food Res. 2005;49:274-84. doi: 10.1002/mnfr.200400109.

23. Grembecka M, Malinowska E, Szefer P. Differentiation of market coffee and its infusions in view of their mineral composition. Sci Total Environ. 2007;383:59-69. doi: 10.1016/j.scitotenv.2007.04.031.

24. Długaszek M, Połec J, Mularczyk-Oliwa M. The content of chosen elements in coffee infusions depending on the method of their preparation. Bromat Chem Toksykol. 2010;43:493-7.

25. Bateman DN, Eagling V, Sandilands EA, Jackson G, Crawford C, Hawkins $L$, et al. Iron overdose epidemiology, clinical features and iron concentration-effect relationships: the UK experience 2008-2017. Clin Toxicol (Phila). 2018:1-9. doi: 10.1080/15563650.2018.1455978.

26. Barabasz W, Albinska D, Jaskowska M, Lipiec J. Ecotoxicology of Aluminium. Pol J Environ Stud. 2002;11:199-203.

27. Rahman MS, Molla AH, Saha N, Rahman A. Study on heavy metals and its risk assessment in some edible fishes from Bangshi River, Savar, Dhaka, Bangladesh. Food Chem. 2012;134:1847-54. doi: 10.1016/j. foodchem.2012.03.099

28. Renieri EA, Sfakianakis DG, Alegakis AA, Safenkova IV, Buha A, Matovic $\mathrm{V}$, et al. Nonlinear response to waterborne cadmium exposure in zebrafish: an in vivo study. Environ Res. 2017;157:173-81.

29. Al-Hossainy AF, Mohamed AE, Hassan FSM, Abd Allah MM. Determination of cadmium and lead in perch fish samples by different pulse anodic stripping voltammetry and furnace atomic absorption spectrometry. Arab J Chem. 2017;10:347-54. doi: 10.1016/j.arabjc.2012.09.005.
30. WHO. Sodium intake for adults and children : guideline. Accessed August 23rd, 2019 at: https://apps.who.int/iris/bitstream/ handle/10665/77985/9789241504836_eng.pdf?sequence=131.

31. Dietary reference intakes for calcium and vitamin D. Institute of Medicine (US) Committee to Review Dietary Reference Intakes for Vitamin D and Calcium. Ross AC, Taylor CL, Yaktine AL, Del Valle $\mathrm{HB}$, editors. Washington (DC): National Academies Press (US), The National Academies Collection: Reports funded by National Institutes of Health), 2011.

32. Tolerable upper intake levels for vitamins and minerals. Accessed August 23rd, 2019 at: http://www.efsa.europa.eu/sites/default/ files/efsa_rep/blobserver_assets/ndatolerableuil.pdf.

33. Eating well with Canada's food guide. Accessed August 23rd, 2019 at: http://www.hc-sc.gc.ca/fn-an/alt_formats/hpfb-dgpsa/pdf/ food-guide-aliment/print_eatwell_bienmang-eng.pdf.

34. Kutsal E, Aydemir C, Eldes N, Demirel F, Polat R, Taspnar O, et al. Severe hypermagnesemia as a result of excessive cathartic ingestion in a child without renal failure. Pediatr Emerg Care. 2007;23:570-2. doi: 10.1097/PEC.0b013e31812eef1c.

35. Kunitake Y, Mizoguchi Y, Sogawa R, Matsushima J, Kato Takahiro A, Kawashima T, et al. Effect of excessive coffee consumption on the clinical course of a patient with bipolar disorder: a case report and literature review. Clin Neuropharmacol. 2017;40:160-2. doi: 10.1097/WNF.0000000000000222.

36. Nedzarek A, Torz A, Karakiewicz B, Clark JS, Laszczynska M, Kaleta $\mathrm{A}$, et al. Concentrations of heavy metals ( $\mathrm{Mn}, \mathrm{Co}, \mathrm{Ni}, \mathrm{Cr}, \mathrm{Ag}, \mathrm{Pb})$ in coffee. Acta Biochim Pol. 2013;60:623-7.

37. Stelmach E, Pohl P, Szymczycha-Madeja A. The content of $\mathrm{Ca}, \mathrm{Cu}$, $\mathrm{Fe}, \mathrm{Mg}$ and $\mathrm{Mn}$ and antioxidant activity of green coffee brews. Food Chem. 2015;182:302-8. doi: 10.1016/j.foodchem.2015.02.105.

38. Nogaim QA, Al-Dalali S, Al-Badany A, Farh M. Determination of some heavy metals in Yemeni green coffee. J Applied Chem. 2014;2:13-8.

39. Oliveira M, Ramos S, Delerue-Matos C, Morais S. Espresso beverages of pure origin coffee: mineral characterization, contribution for mineral intake and geographical discrimination. Food Chem. 2015;177:330-8. doi: 10.1016/j.foodchem.2015.01.061.

40. Fosmire GJ. Zinc toxicity. Am J Clin Nutr Zinc toxicity. 1990;51:2257. doi: $10.1093 /$ ajen/51.2.225. 